\section{Doctors and the prevention of nuclear war}

\author{
John Launer
}

In 1985 the Nobel Peace Prize was won not by an individual but by an organisation, International Physicians for the Prevention of Nuclear War. IPPNW had been founded only five years earlier, by a small group of doctors in the United States and the Soviet Union. In a short time, it drew together over 130,000 doctors from 41 countries. IPPNW worked through two parallel strategies: building links between medical professionals from east and west, and educating people on the medical effects of nuclear weapons. As a member of its British affiliate, the Medical Campaign Against Nuclear Weapons, I joined a delegation of doctors who visited Russia in $1983 .{ }^{1}$ Our formal mission was to learn about maternal and child care around Russia. Our informal purpose - known to everyone including our hosts - was to promote friendship and reduce the mutual suspicion that pervaded nearly all communication between Eastern Europeans and westerners.

Through such activities, and a series of international conferences, doctors worldwide made an important contribution to the process of "détente" that reduced tension between the world's two major power blocs during the Cold War. The founding co-presidents of IPPNW, Bernard Lown and Yevgeny Chazov, were particularly effective in this regard. Lown, a professor of cardiology at Harvard, was famous as the developer of the DC defibrillator. Chazov was head of the Moscow Institute of Cardiology and close to the Soviet leader Mikhail Gorbachev. In his memoirs, Gorbachev described how his meetings with the two men profoundly influenced his views on nuclear weapons, and contributed to his decision to end nuclear testing unilaterally, and reduce stockpiles of weapons.

On the educational front, members of IPPNW everywhere taught and wrote about the biological, physical and psychological consequences that an exchange of nuclear weapons could bring about. $^{2} 3$ I can remember giving talks in church halls

Correspondence to Dr John Launer, Professional Development Department, Health Education England, Stewart House, 32 Russell Square, London WC1B 5DN, UK: john.launer@nwl.hee.nhs.uk and sixth form assemblies, showing slides of what would happen to London as a result of four relatively "small" bombs. "Are the Soviets paying you to tell us this?" one sceptical schoolgirl asked me. The Nobel Peace Prize Committee took a different view of our project. "It is the committee's opinion", they announced, "that this organisation has performed a considerable service to mankind by spreading authoritative information and by creating an awareness of the catastrophic consequences of atomic warfare". ${ }^{4}$

\section{CHALLENGING COMPLACENCY}

Since the breakup of the Soviet Union, awareness of the risks presented by nuclear weapons has reduced, both among doctors and in the general public. The information is certainly available if you want to find it: there is even now a website where you can calculate what would happen to your own city as a result of warheads of various sizes landing there. ${ }^{5}$ Yet most people assume that any nuclear war, if it ever happened, would only occur in the distant future, and probably between a couple of unstable nations a long way away. To most people, it certainly seems less of a threat than climate change, even though it would be immeasurably quicker and more devastating.

There is little reason for complacency. Writing about nuclear weapons in the New England Journal of Medicine a year ago, Ira Helfand and Victor Sidel, set out the facts in uncompromising terms: "There remain in the world today more than 15,000 nuclear warheads, $95 \%$ of which are in the arsenals of the United States and Russia. Of these warheads, some 2000 are on hairtrigger alert. They can be fired in less than 15 minutes and can destroy their targets across the globe 30 minutes later. These weapons pose an existential threat to humanity. If just 300 Russian warheads got through to targets in the United States, 75 million to 100 million people would die from the blast and heat effects in the first half hour. In addition, the entire economic infrastructure on which we depend would be destroyed. The public health system, the communications network, the electric grid, the banking system, the food distribution system - all would be gone. In the months after such an attack, the vast majority of
Americans not killed in the initial attack would die from starvation, radiation sickness, epidemic disease, or exposure to the elements. A corresponding U.S. attack would create the same devastation in Russia, and if NATO were drawn into the war, much of Europe would suffer the same fate".

They continue: "A war involving the strategic weapons deployed today by the United States and Russia would generate some 150 million tons of soot, enough to reduce temperatures around the world by an average of $8^{\circ} \mathrm{C}$. In the interior regions of North America and Eurasia, temperatures would drop by as much as $30^{\circ} \mathrm{C}$, to levels not seen in 18,000 years, since the coldest point of the last ice age. Food production would collapse, the vast majority of the human race would starve, and it's possible that our species would become extinct". ${ }^{6}$

\section{DESPAIR AND HOPE}

These catastrophic risks do not depend on nuclear war being launched intentionally. It could result from terrorism, cyberattack or, far more likely, by mistake. There have been at least five documented occasions on which Moscow or Washington prepared to launch weapons, in the mistaken belief that the other side had begun an attack. The US and Russian presidents each have around 20 minutes in which to decide whether evidence of such an attack warrants retaliation. The chain of command and technology leading to a US launch involves the use of telephone landlines, and an obsolete computer system that employs "floppy discs" from the 1970s. The launch sites have a record of employing operatives who have then been dismissed for misuse of alcohol and drugs, or imprisoned for violence. ${ }^{7}$ As many people have also pointed out, Donald Trump's impulsive and volatile temperament seems frighteningly ill-suited to military decision-making under pressure. $\mathrm{He}$ already appears to have rejected the longestablished principles of non-proliferation and "no first use", instead encouraging other allies to acquire nuclear weapons to defend themselves against their enemies. Recently, both he and the Russian president have broken with established practice and talked of the need to increase their nations' nuclear capability, suggesting a very shallow understanding of the risks, given existing capability. It would be easy now to despair about any prospect of preventing nuclear war.

Yet the last few months have also brought at least one small cause for hope. On October 27th, just two weeks before 
the US presidential election and with vastly less publicity, 123 countries voted at the United Nations to move forward on negotiations to outlaw nuclear weapons, along the lines of established bans on biological and chemical weapons.

Although five of the nine current nuclear powers voted against the resolution (Russia, the US, the United Kingdom, France and Israel), China chose to abstain for the first time. So did India and Pakistan, while North Korea surprisingly voted in favour. The Netherlands broke ranks with the opposition from NATO and its allies to ban treaty talks, after grassroots pressure on its Parliament. Discussions will now proceed on a framework for making possession of nuclear weapons illegal.

As one observer from IPPNW has written, the discourse at the United Nations has finally shifted from examining deterrence and security, to an understanding of the overwhelming deaths and devastation people would suffer from the use of nuclear weapons. ${ }^{8}$ IPPNW is now renewing efforts to build relationships with Russian physicians, and to explore possibilities to meet with physicians in the two Asian nuclear states that have broken with the big-power nuclear consensus. Doctors have acted as peacemakers in a previous time of danger. With determination, we might be able to do it again.

Twitter Follow John Launer, @JohnLauner

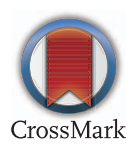

To cite Launer J. Postgrad Med J 2017;93:111-112. Postgrad Med J 2017;93:111-112. doi:10.1136/postgradmedj-2017-134799

\section{REFERENCES}

1 Launer J. Personal view. BMJ 1984;288:1687.

2 The medical consequences of thermonuclear war. NEJM 1962;266:1126-25.

3 British Medical Association Board of Science and Education. The Medical Effects of Nuclear War. Oxford, Wiley-Blackwell, 1983.

4 Official statement of the Nobel Prize Committee upon awarding the 1985 Nobel Peace Prize to IPPNW. 11 Oct 1985. http://www.ippnw.org/nobel-peace-prize. html (accessed 30 Jan 2016).

5 Nukemap. Restricted Data [blog]. http://nuclearsecrecy. com/nukemap/ (accessed 30 Jan 2016).

6 Helfand I, Sidel VW. Docs and nukes - still a live issue. NEJM 2015;373:1901-03.

7 Schlosser E. World War Three, By Mistake. The New Yorker, 23 Dec 2016. http://www.newyorker.com/ news/news-desk/world-war-three-by-mistake (accessed 30 Jan 2016).

8 Slater A. The United Nations Votes to Start Negotiations to Ban the Bomb. The Nation, 1 Nov 2016. https://www.thenation.com/article/unitednations-votes-to-start-negotiations-to-ban-the-bomb/ (accessed 30 Jan 2016). 